\title{
Sonbahar ve ilkbahar ekimlerinin haşhaşın (Papaver somniferum L.) verim ve morfin içeriği üzerine etkisi
}

\author{
The effect of autumn and spring sowing on yield and morphine content of poppy (Papaver somniferum L.)
}

Aytuğ Emrah AYHAN ${ }^{1}$ (D) Mehmet Uğur YILDIRIM $^{1 / D}$

${ }^{1}$ Uşak University, Faculty of Agriculture, Department of Field Crops, Uşak, Turkey.

MAKALE BILGISI / ARTICLE INFO

Makale tarihçesi / Article history:

DOI: $10.37908 / m k u t b d .931221$

Geliş tarihi /Received:02.05.2021

Kabul tarihi/Accepted:22.06.2021

\section{Keywords:}

Alternative sowing time, global warming, secondary metabolite, alkaloid.

\footnotetext{
Corresponding author: M. Uğur YILDIRIM
}

$\bowtie$ : ugur.yildirim@usak.edu.tr

\section{ÖZET / A B STR A C T}

Atıf / Citation: Ayhan AE, Yıldırım MU (2021) Sonbahar ve ilkbahar ekimlerinin haşhaşın (Papaver somniferum L.) verim ve morfin içeriği üzerine etkisi. MKU. Tar. Bil. Derg. 26(2) : 412-420. DOI: 10.37908/mkutbd.931221

\section{GíRiş}

Türkiye farklı iklim ve topoğrafik özelliklere sahip olmasından dolayı birçok bitki türünün gen merkezi olarak bilinmektedir. Tıbbi, aromatik ve keyf bitkileri bu türler içerinde önemli bir yere sahiptir. Keyf bitkileri içerisinde stratejik bir öneme sahip olan haşhaş bitkisi
(Papaver somniferum L.) Anadolu'nun geleneksel bir ürünüdür ve yüzyıllardır bu coğrafyada tarımı yapılmaktadır. Haşhaş Papaveraceae familyasında yer almaktadır, bu familya 28 cins ve yaklaşık 250 tür barındırmaktadır (Davis ve ark., 1988). Türkiye'de bu familyaya ait 7 cinsten bir tanesi olan Papaver cinsi içerisinde 25 tanesi tek ve 20 tanesi çok yıllık olmak üzere 
toplamda 45 adet türün bulunduğu ve bunlardan da 15 tanesinin endemik olduğu belirtilmektedir (Anonim, 2021)

Haşhaşın Anadolu'da Hititliler döneminde tarımının yapıldığı ve o günden bu güne değin farklı kaynaklarda bu bölgede yetiştirildiği belirtilmektedir. Hatta Pierre Belon adında bir Fransız araştırmacı 1500'lü yılların başında Anadolu'ya gelmiş ve Fransızların buğdayı yetiştirdikleri gibi Türklerin de haşhaş yetiştirdiğinden bahsetmiştir (Incekara, 1949; Sarıhan, 2004).

Haşhaş bitkisi $60 \mathrm{~cm}$ ile $200 \mathrm{~cm}$ arasında boylanabilen, çiçekleri beyazdan mavi viyoleye kadar farklı renklerde olabilen, kapalı kapsüllü tek yıllık bir bitkidir (Eser ve ark., 2006). Ege bölgesi ağırlıklı olmak üzere, Türkiye'de 13 ilde üretim izinli olarak yetiştirilmektedir. Haşhaş tohumları beyaz-kirli beyaz renkten, gri, sarı, kahverengi, pembe, mavi renge kadar farklı tonlarda olabilmektedir. $\mathrm{Bu}$ tohumlar doğrudan veya ezilerek hamur işlerinde kullanılmaktadır. Haşhaş tohumunda \%40-50 yağ bulunmaktadır ve çabuk kuruyan yağlardan olduğu için resimden boyacılığa kadar sanayinin farklı kollarında kullanılmaktadır. Tohumda protein oranı ise \%20-30 arasında değişmektedir (Rezaeı Osalou, 2015). Haşhaş, tohumlarının besleyici özelliğinin yanı sıra kuru kapsülleri süs bitkisi olarak da değerlendirilebilmekte, hatta morfin oranı düşük hat ve çeşitler gösterişli çiçeklerinden dolayı park ve bahçelerde kullanılmaktadır.

Haşhaş bitkisi, kapsüllerinden elde edilen morfin, kodein, tebain, noskapin ve papaverin gibi alkaloidler nedeni ile de tıbbi amaçla kullanılmakta ve stratejik bir bitki olarak da değerlendirilmektedir (Er ve Yıldız, 2007). Alkaloidler; ağrı kesici, spazm giderici, uyku hali oluşturma, öksürük kesici gibi özelliklerinden dolayı ilaç sanayinin hammaddesi olarak kullanılmaktadır.

Türkiye, geleneksel haşhaş üreticisi ülke olarak kabul edilmektedir ve dünyada yasal olarak ekim yapılan alanlarının yaklaşık \%50'ne sahip bulunmaktadır (İnan, 2013). Bu oran yıldan yıla değişim göstermektedir. 2019 yılında dünya morfin amaçlı yasal haşhaş üreticisi ülkelerin toplam ekim alanı 87642 hektar olarak gerçekleşmiştir. Bu alan içerisinde de Türkiye 56511 hektar ile \%59 luk bir pay almıştır (Anonim, 2020). Haşhaş alkaloidleri, 1972 yılana kadar kapsüller çizilerek elde edilirken 1974 yılından sonra çizim yasaklanmış ve kuru kapsüllerden morfin elde edilmeye başlanmıştır.

Haşhaş ekiminin büyük bir bölümü batı kesimlerde özellikle de Ege Bölgesinde yapılmaktadır. Ekimler genellikle sonbaharda (kışlık) yapılmakta, kar yağışının olmadığı ve kışı sert geçen yıllarda haşhaş ekimi erken ilkbaharda tekrar yenilenmektedir. Sonbaharda ekilen bitkilerin rozet oluşum döneminde kışa girmesi kış soğuklarına karşı mukavemetini arttırmaktadır. Kış sonunda seyreltme ve çapalama ile gelişimleri hızlanmakta ve bakım işleri verime önemli katkı sağlamaktadır. İlkbahar ekimleri Şubat ve Mart ayları içerisinde yapılmakta ve sonrasında artan sıcaklar bitkinin çabuk sapa kalkmasına neden olmaktadır. Bitkiler çabuk çiçek açıp kapsül oluşturmak zorunda kaldıklarından verimde düşüşler meydana gelebilmektedir. Küresel ısınma ve iklim değişikliği nedeni ile de son yıllarda ortalama sıcaklıkların yükselmesi ve yağış rejimindeki değişiklikler bitki gelişimini ve verimi olumsuz şekilde etkilemektedir. Illkbahar (yazlık) ekiminin dezavantajları olmasına rağmen haşhaş ekim alanlarında ve Uşak'ta bazı yıllarda ilkbaharda ekim yapılmak zorunda kalınmaktadır. Sonbahar ve ilkbahar ekimlerinin kıyaslanması veya sonbahar ekimine alternatif ilkbahar ekim zamanlarının belirlenmesi konusunda çalışmaların az olması da dikkat çekmektedir.

Bu çalışmada; küresel ısınmanın etkilerini daha fazla hissetmeye başladığımız son yıllarda, Türkiye tarım ekonomisinde önemli olduğu kadar sosyal ve politik hayatta da etkili bir yeri olan haşhaşın Uşak ilinde sonbahar ekimine alternatif olarak en uygun ilkbahar ekim zamanının belirlenmesi amaçlanmıştır.

\section{MATERYAL ve YÖNTEM}

Denemede, Toprak Mahsulleri Ofisi tarafından Uşak'da ekimi yaptırılan Papaver somniferum L. türüne ait Ofis 3 çeşidi materyal olarak kullanılmıştır. Ofis 3; kapsüldeki morfin oranı ortalama \%1.14, yağ oranı \%49.55, kapsülleri puslu, tohum rengi mavi, çiçek rengi açık viyole ve soğuğa mukavemeti olan bir çeşittir. Bu çalışma Uşak illi Koyunbeyli Köyünde çiftçi tarlasında bulunan deneme parselinde yürütülmüştür. Tarla denemeleri birinci yıl 2017 sonbahar ve 2018 ilkbahar, ikinci yıl 2018 sonbahar ve 2019 ilkbahar ekimleri olarak yürütülmüştür.

Denemede, sonbahar ekimleri her iki yılda kasım ayında (15.11.2017, 15.11.2018 tarihlerinde) yapılmıştır. Denemede ilkbahar ekim zamanları ise her iki yılda a) 1 Şubat 2018 ve 2019, b) 15 Şubat 2018 ve 2019, c) 1 Mart 2018 ve 2019, d) 15 Mart 2018 ve 2019 tarihlerinde olmak üzere 4 farklı zamanda yapılmıştır. Sonbahar ekimine alternatif ilkbahar ekim zamanlarının belirlenmesi amaçlandığı için 4 farklı ilkbahar ekimi planlanmıştır. Ancak mart başı ve ortasında yapılan ekimlerden sonuç alınamamıştır. Deneme üç tekrarlamalı olarak tesadüf blokları deneme desenine göre kurulmuş ve yürütülmüştür. Parsellerde sıra boyu 3 $\mathrm{m}$, sıra arası mesafeler $25 \mathrm{~cm}$ olarak ayarlanmıştır.

Deneme yerinin toprak analiz sonuçlarına göre; toprağın killi, tuzsuz, hafif alkali, yüksek oranda kireçli, organik 
madde bakımından düşük olduğu tespit edilmiş. Toprakta ayrıca azot, fosfor ve sodyum miktarının düşük, potasyum, kalsiyum ve magnezyum elementlerinin miktarının yüksek olduğu tespit edilmiştir. Denemeye ekimle birlikte $6 \mathrm{~kg} \mathrm{da}^{-1}$ azot ve fosfor gelecek şekilde 2020 kompoze gübresi taban gübresi olarak verilmiştir.
Denemenin kurulduğu 2017-2018 ve 2018-2019 yıllarında haşhaş yetiştirme dönemi boyunca deneme yerine ait aylık toplam yağış $(\mathrm{mm})$ ve aylık ortalama sıcaklık $\left({ }^{\circ} \mathrm{C}\right)$ değerleri ile uzun yıllar ortalama değerleri Çizelge 1 de verilmiştir.

Çizelge 1. Denemenin yapıldığı dönemde Uşak iline ait iklim verileri*

Table 1. Climate data of Uşak province during the experiment period*

\begin{tabular}{lcccccc}
\hline AYLAR & \multicolumn{3}{c}{ YAĞIŞ $(\mathbf{m m})$} \\
\cline { 2 - 7 } & $2017 / 2018$ & $2018 / 2019$ & Uzun Yıllar & $2017 / 2018$ & $2018 / 2019$ & Uzun Yıllar \\
EYLÜL & 31.2 & 0.1 & 18.6 & 21.6 & 20.4 & 19.1 \\
EKIM & 63.3 & 74.1 & 42.2 & 12.9 & 14.8 & 13.6 \\
KASIM & 43.2 & 68.7 & 58.9 & 7.6 & 9.5 & 8.2 \\
ARALIK & 52.8 & 110.3 & 84.6 & 5.6 & 3.6 & 4.1 \\
OCAK & 71.8 & 87.9 & 73.4 & 3.6 & 1.6 & 2.2 \\
ŞUBAT & 63.8 & 17.3 & 66.7 & 6.7 & 5.4 & 3.2 \\
MART & 76.8 & 20.8 & 58 & 9.3 & 7.8 & 6.1 \\
NiSAN & 6.4 & 40.1 & 50.9 & 15.4 & 10.5 & 10.8 \\
MAYIS & 102.4 & 36.9 & 48 & 17.2 & 16.7 & 15.5 \\
HAZIRAN & 54.6 & 37.3 & 27.2 & 20.2 & 20.9 & 19.9 \\
TEMMUZ & 58.2 & 8.9 & 16.5 & 23.7 & 22.8 & 23.3 \\
\hline
\end{tabular}

*Veriler Meteoroloji Genel Müdürlüğünden Temin Edilmiştir.

Yetiştirme dönemindeki yağış miktarının birinci yıl nisan ayında ikinci yıl ise şubat, mart, nisan ve mayıs aylarında uzun yıllar ortalamalarına göre daha az olduğu, birinci yıl mayıs, haziran ve temmuz, ikinci yıl kasım, aralık, ocak ve haziran aylarında uzun yıllar ortalamalarına göre daha fazla yağış aldıkları görülmektedir. Birinci yıl nisan ayı yağışı $(6.4 \mathrm{~mm})$ oldukça az olmuştur. Ancak mayıs ve haziran ayında, yağış miktarı uzun yıllar ortalamasının (mayıs: $48 \mathrm{~mm}$; haziran: $27.2 \mathrm{~mm}$ ) neredeyse iki katı kadar (mayıs: $102.4 \mathrm{~mm}$ ve haziran: $54.6 \mathrm{~mm}$ ) gerçekleşmiştir.

Gerçekleşen aylık ortalama sıcaklıkların ise vejetasyon süresi boyunca genel olarak ortalama değerlerden daha yüksek olduğu dikkat çekmektedir. 2017/2018 yetiştirme periyodunda vejetasyon süresi boyunca sıcaklıklar ortalama değerlerden yüksek olmuş ve nisan ayında ortalama değerlerin 4.6 ㅇ üzerinde seyretmiştir. íkinci yılda şubat ayından itibaren sıcaklıkların genel olarak ortalama değerlerden yüksek olduğu dikkat çekmektedir (Çizelge 1). Şubat ve mart ayı içerisindeki ekimlerin ani sıcaklık artışından olumsuz etkilendikleri gözlemlenmiştir. Araştırmadan elde edilen verilerin varyans analizleri SPSS paket programında yapılmıştır. Ortalamalar arasındaki farklar Duncan testi ile belirlenmiştir.

\section{BULGULAR ve TARTIŞMA}

Denemenin birinci ve ikinci yılında Mart ayı içerisinde yapılan 3. ve 4. ilkbahar ekimlerinde yeterli bitki gelişimi olmadığı için bu tarihlere ait ekimler değerlendirmeye alınmamıştır. Her iki yıl vejetasyon süresi boyunca sıcaklıkların uzun yıllar ortalamalarına göre yüksek seyretmesi ve yağışlardaki düzensizliklerden dolayı bitki gelişimleri olumsuz etkilenmiştir. Özellikle mart ayı içerisindeki ekimlerde bitkiler gelişimlerini tamamlayamamış ve herhangi bir verim alınamamıştır. Bu nedenle, sonbahar ekimi ile birlikte şubat ayının başında ve ortasında yapılan ekimlerden elde edilen sonuçlar değerlendirilmiştir. Yapılan istatistik analizine göre yıllara ait ortalama değerler arasındaki fark önemli çıkmadığı için, her yılın istatistik analizi ayrı ayrı yapılmıştır. İncelenen parametrelerin birinci ve ikinci yıla ait ortalama değerleri Çizelge 2 'de verilmiştir. 
Çizelge 2. Birinci ve ikinci yıl ölçülen karakterlere ait ortama değerler Table 2. Average values of measured characters in the first and second year

\begin{tabular}{|c|c|c|c|c|c|c|c|}
\hline $\begin{array}{l}\text { Ekim } \\
\text { Tarihleri }\end{array}$ & $\begin{array}{l}\text { Bitki Boyu } \\
\text { (cm) }\end{array}$ & $\begin{array}{l}\text { Kitki Başıñ } \\
\text { Kapsül } \\
\text { Sayısı } \\
\text { (adet) }\end{array}$ & $\begin{array}{c}\text { Kapsül } \\
\text { boyu (mm) }\end{array}$ & $\begin{array}{l}\text { Kapsül Eni } \\
\text { (mm) }\end{array}$ & $\begin{array}{c}\text { Kapsül } \\
\text { Verimi } \\
\left(\mathrm{kg} \mathrm{da}^{-1}\right)\end{array}$ & $\begin{array}{l}\text { Tohum } \\
\text { Verimi } \\
\left(\mathrm{kg} \mathrm{da}^{-1}\right)\end{array}$ & $\begin{array}{c}\text { Morfin } \\
\text { Verimi (\%) }\end{array}$ \\
\hline 15.11 .2017 & $82.70 \mathrm{a} * *$ & $1.27 \mathrm{a} *$ & $50.07 \mathrm{a} * *$ & $29.97 \mathrm{a} * *$ & $105,28 a^{* *}$ & $112.61 \mathrm{a}^{* *}$ & $1.17 b^{*}$ \\
\hline 01.02 .2018 & $36.09 \mathrm{~b}$ & $1.10 \mathrm{~b}$ & $28.93 \mathrm{~b}$ & $15.23 \mathrm{~b}$ & $20.83 \mathrm{~b}$ & $23.67 \mathrm{~b}$ & $1.46 \mathrm{a}$ \\
\hline 15.02.2018 & $34.25 \mathrm{~b}$ & $1.04 \mathrm{~b}$ & $29.37 \mathrm{~b}$ & $15.77 \mathrm{~b}$ & $21.67 \mathrm{~b}$ & $23.00 \mathrm{~b}$ & $1.45 \mathrm{a}$ \\
\hline $\begin{array}{l}\text { 1. Yıl } \\
\text { Ortalama }\end{array}$ & 51.01 & 1.14 & 36.12 & 20.32 & 49.24 & 53.09 & 1.36 \\
\hline 15.11.2018 & $86.20 a^{* *}$ & $1.33 \mathrm{a}^{* *}$ & $49.30 \mathrm{a} * *$ & $30.80 * *$ & $107.11 \mathrm{a}^{* *}$ & $116.78 a^{* *}$ & 1.07 \\
\hline 01.02.2019 & $34.79 \mathrm{~b}$ & $1.02 \mathrm{~b}$ & $28.73 \mathrm{~b}$ & 15.10 & $18.39 \mathrm{~b}$ & $21.11 b$ & 1.29 \\
\hline 15.02.2019 & $33.54 \mathrm{~b}$ & $1.03 \mathrm{~b}$ & $28.70 \mathrm{~b}$ & 15.47 & $17.55 \mathrm{~b}$ & $19.83 \mathrm{~b}$ & 1.31 \\
\hline $\begin{array}{l}\text { 2. Yıl } \\
\text { Ortalama } \\
\text { íki Yılın }\end{array}$ & 51.51 & 1.13 & 35.58 & 23.12 & 47.68 & 52.57 & 1.22 \\
\hline $\begin{array}{l}\text { Genel } \\
\text { Ortalaması }\end{array}$ & 51.26 & 1.14 & 35.85 & 21.72 & 48.46 & 52.83 & 1.29 \\
\hline
\end{tabular}

** $p<0.01$ aynı yıl aynı sütunda verilen ortalama değer arasındaki farklar istatistiki olarak önemlidir

* $p<0.05$ aynı yıl aynı sütunda verilen ortalama değer arasındaki farklar istatistiki olarak önemlidir

\section{Bitki boyu (cm)}

Bitki boyuna ait değerlerin birinci yıl $34.25-82.70 \mathrm{~cm}$, ikinci yıl 33.54-86.20 cm arasında değiştiği belirlenmiştir (Çizelge 2). Her iki yılda en yüksek bitki boyu sonbahar ekimlerinden elde edilmiştir. Illkbahar ekimlerinde bitki boyunun ciddi şekilde azaldığı tespit edilmiştir. Sonbahar ve ilkbahar ekimlerinde bitki boyu ortalama değerleri arasındaki farkların önemli olduğu $(p<0.01)$ ve farklı gruplarda yer aldıkları görülmektedir (Çizelge 2).

Bitki boyunu; Gümüşcü (2002) 99.33-116.1 cm, Engin (1995) 74.7-94.7 cm, Erdurmuş (1989) 79.40-114.65 cm, Büyükgöçmen (1993) 60-98 cm, Gümüşcü (1996) 66.35$98.75 \mathrm{~cm}$, Sarıhan (2004) 102.131-106.594 cm, Karadavut (1994) 22.21-99.71, Rezaeı Osalou (2015) 90.3-112.5 cm, Boydak ve Kavurmacı (2015) 70,57-85,67, Alaca (2015) 95.82-100.32 cm arasında bulmuşlardır. Araştırmacıların bulmuş oldukları değerler denemede sonbahar ekimlerinden elde ettiğimiz değerler ile benzerlik göstermekte, fakat ilkbahar ekimlerinden elde ettiğimiz değerlerin daha düşük olduğu dikkat çekmektedir. Araştırmacılar denemelerini genellikle sonbahar ekimi olarak planlamışlar ve elde edilen bitki boyu değerleri bizim aynı dönemde ektiğimiz haşhaşlardan elde ettiğimiz değerlere paralellik göstermiştir. Gümüş̧̧ü ve Arslan (1999) yapmış oldukları çalışmalarında ilkbaharda ekilen haşhaşlarda bitki boyunu $60.0-91.6 \mathrm{~cm}$, sonbaharda ise $66.35-98-75 \mathrm{~cm}$ olarak tespit etmişlerdir. Sonbahar ekiminde bitki boyu daha uzun olarak ölçülmüş, fakat bu denemede elde edilen değerler gibi aralarında büyük farklılıklar oluşmamıştır. Bunda en büyük etkinin; bitkilerin genetik yapılarından, ekolojik faktörlerden, özellikle bahar aylarında sıcaklıkların ortalama değerlerden yüksek olması ve yağış miktarlarının ortalama değerlerden sapma göstermesinden kaynaklandığı düşünülmektedir.

\section{Bitki başına kapsül sayısı (adet)}

Bitki başına kapsül sayısına ait ortalama değerlerin birinci yıl 1.04-1.27 adet, ikinci yıl 1.02-1.33 adet arasında değiştiği, sonbahar ve ilkbahar ekimleri ortalama değerleri arasındaki farkların istatistiki olarak önemli olduğu $(p<0.05)$ ve farklı gruplarda yer aldığı görülmektedir (Çizelge 2).

Bitki başına kapsül sayısını; Büyükgöçmen (1993) 1.304.39 adet, Karadavut (1994) 1.01- 6.17 adet Soyalp (1996) 1.20-3.07 adet, Erdurmuş (1989) 1.95-7.20 adet, Gümüşçü (2002) 2.93-5.53 adet, Sarıhan (2004) 1.253.40 adet, Inan (2013) 1.93-2.90 adet, Boydak ve Kavurmacı (2015) 3.03-4.47 adet, Alaca (2015) 1.47-2.13, Kara (2017) 1.36-7.36 adet arasında bulmuşlardır. Bu çalışmadan elde edilen kapsül sayılarının araştırmacıların bulduklarından daha düşük olduğu görülmektedir.

Gümüş̧̧ü (1996) sonbaharda yapılan ekimlerde bitki başına kapsül sayısını 2.30-9.58 adet, ilkbaharda ise 1.93- 
3.55 adet arasında bulmuştur. Ilkbahar ekimlerinde kapsül sayısının az olduğu gözlemlenmiş, bunun nedeninin ise vejetasyon süresinin kısa olmasından dolayı bitkinin dal sayısının düşüklüğünden kaynaklandığı sonucuna ulaşılmıştır.

Aynı zamanda sıra arası mesafenin dar tutulması kardeşlenme ve kapsül sayısını da olumsuz etkilemiştir. Diğer araştırmacıların sıra arası mesafeleri genel olarak 40-45 cm arasında değişmiştir.

\section{Kapsül boyu (mm)}

Kapsül boyuna ait ortalama değerlerinin birinci yıl 28.93$50.07 \mathrm{~mm}$, ikinci yıl 28.70-49.30 mm arasında değiştiği, sonbahar ve ilkbahar ekimleri ortalama değerleri arasındaki farkların istatistiki olarak önemli olduğu $(p<0.01)$ ve farklı gruplarda yer aldığı görülmektedir (Çizelge 2).

Kapsül boyunu, Büyükgöçmen (1993) $2.76-4.29 \mathrm{~cm}$, Gümüşcü (1996) 3.48-4.16 cm, Gümüşcü (2002) 3.37$4.35 \mathrm{~cm}$, Sarıhan (2004) 37.215-45.342 mm olarak bulmuşlardır. Araştırmacılar denemelerini genellikle sonbahar ekimi olarak planlamışlar, elde edilen kapsül boyu değerleri bu çalışmada sonbahar ekimlerinde daha yüksek olarak elde edilmiştir. İlkbahar ekimlerinden elde edilen kapsüller tam gelişmeden olgunlaştığı için kapsül boyları sonbahar ekimlerine göre daha küçük olarak tespit edilmiştir.

\section{Kapsül eni (mm)}

Kapsül enine ait ortalama değerlerin birinci yıl 15.23$29.97 \mathrm{~mm}$, ikinci yıl 15.10-30.80 mm arasında değiştiği, sonbahar ve ilkbahar ekimleri ortalama değerleri arasındaki farkların istatistiki olarak önemli olduğu $(p<0.01)$ ve farklı gruplarda yer aldığı görülmektedir (Çizelge 2).

Kapsül enini, Sarıhan (2004) $2.95-4.73 \mathrm{~cm}$, Karadavut (1994) $0.56-2.30 \mathrm{~cm}$, Gümüşcü (1996) $2.67-4.20 \mathrm{~cm}$, Gümüşcü (2002) 4.26-5.11 cm, Büyükgöçmen (1993) 2.43-3.98 cm, olduğunu belirtmişlerdir. Araştırmacılar denemelerini genellikle sonbahar ekimi olarak planlamışlardır. Denemeden elde edilen kapsül enine ait değerler Karadavut (1994) dışında diğer araştırmacıların bulduğu değerlerden daha düşük olarak bulunmuştur.

Kapsül boyunda olduğu gibi kapsül enine ait değerlerin de ilkbahar ekimlerinde sonbahar ekimlerine göre daha düşük olduğu tespit edilmiştir. Illkbahar ekimlerinde sıcaklıkların aniden artması ve mevsim ortalamalarına göre daha yüksek seyretmesi nedeni ile kapsüllerin tam gelişemeden olgunlaşmasından kaynaklandığı değerlendirilmektedir.

\section{Kapsül verimi ( $\left.\mathrm{kg} \mathrm{da}^{-1}\right)$}

Kapsül verimine ait ortalama değerlerin birinci yıl 20.83$105.28 \mathrm{~kg} \mathrm{da}^{-1}$, ikinci yıl $17.55-107.11 \mathrm{~kg} \mathrm{da}^{-1}$ arasında değiştiği, sonbahar ve ilkbahar ekimleri ortalama değerleri arasındaki farkların istatistiki olarak önemli olduğu ve farklı gruplarda yer aldığı görülmektedir (Çizelge 2).

Dekara kapsül verimini, Sarıhan(2004) 54.250-136.969 $\mathrm{kg} \mathrm{da}^{-1}$, Koç (2000) 44.5-113.5 kg da-1, Engin (1995) 66.7$91.0 \mathrm{~kg} \mathrm{da}{ }^{-1}$, Erdurmuş (1989) 73.54-173.56 kg da-1, Gümüşcü (1996) 55.54-116.00 kg da-1, Gümüşcü (2002) 45.03-133.1 kg da-1, Soyalp (1996) 44.12-95.81 kg da-1 olarak bildirilmiştir. Araştırmacılar denemelerini genellikle sonbahar ekimi olarak planlamışlar ve bulmuş oldukları değerler denemede sonbahar ekimlerinden elde edilen değerler ile benzerlik göstermiştir. Fakat ilkbahar ekimlerden elde edilen değerlerin daha düşük olduğu dikkat çekmektedir. Sonbahar ve ilkbahar ekimleri arasında oluşan kapsül verim farklarının, ilkbahar ekilişlerde vejetasyon süresinin kısa olması ve sıcaklıkların artması nedeni ile kapsüllerin erken olgunlaşmak zorunda kalması, mevsim yağışlarının yetersiz ve düzensiz olması gibi nedenlerden kaynaklandığı düşünülmektedir.

\section{Tohum verimi $\left(\mathrm{kg} \mathrm{da}^{-1}\right)$}

Tohum verimine ait ortalama değerlerin birinci yıl 23.00$112.61 \mathrm{~kg} \mathrm{da}^{-1}$, ikinci yıl $19.83-116.78 \mathrm{~kg} \mathrm{da}^{-1}$ arasında değiştiği, sonbahar ve ilkbahar ekimleri ortalama değerleri arasındaki farkların istatistiki olarak önemli olduğu $(p<0.01)$ ve farklı gruplarda yer aldığı görülmektedir (Çizelge 2).

Dekara tohum verimini, Koç (2000) $55.2-144.6 \mathrm{Kg} \mathrm{da}^{-1}$, Sarıhan (2004) 58.606-144.513 kg da-1, Engin (1995) 98.5 - $125.3 \mathrm{~kg} \mathrm{da}^{-1}$, Malinia ve Ivanova (1975) $34-98 \mathrm{~kg} \mathrm{da}^{-1}$, Gümüşcü (1996) 44.93-128.11 kg da-1, Gümüşcü (2002) $51.20-151.1 \mathrm{~kg} \mathrm{da}^{-1}$, Soyalp (1996) $50.48-109.20 \mathrm{~kg} \mathrm{da}^{-1}$ olarak bildirilmiş, araştırmacıların bulmuş oldukları bu değerler denemede sonbahar ekimlerinden elde edilen değerler ile benzerlik göstermekte, fakat ilkbahar ekimlerinden elde edilen değerlerin daha düşük olduğu dikkat çekmektedir. Araştırmacılar denemeyi genellikle sonbahar ekimi olarak planlamışlar ve elde edilen tohum verimi değerleri bu denemede aynı dönem ekilen haşhaşlardan elde edilen değerlere paralellik göstermektedir. Sonbahar ve ilkbahar ekimleri arasında oluşan tohum verim farkları, ilkbahar ekilişlerde vejetasyon süresinin kısa olması, havaların ısınması ile bitki neslini devam ettirebilmek için generatif devreye vejetatif gelişimini tamamlayamadan erken girmesi ile kapsüllerin daha küçük kalması ve tohum verimine doğrudan etki ettiği şeklinde değerlendirilmektedir. 


\section{Morfin verimi (\%)}

Morfin verimine ait ortalama değerlerin birinci yıl \%1.17\%1.46, ikinci yıl \%1.07-\%1.31 arasında değiştiği, sonbahar ekimi ile ilkbahar ekimleri ortalama değerleri arasındaki farkların istatistiki olarak önemli olduğu $(p<0.05)$ ve farklı gruplarda yer aldığı görülmektedir (Çizelge 2).

Morfin verimini, Gümüşcü (1996) \%0.53-\%0.98, Büyükgöçmen (1993) \%0.21-\%0.74, Karadavut (1994) $\% 0.22-\% 1.22$, Gümüşcü (2002) \%0.421-\%0.739, Sarıhan (2004) \%0.473-\%0.711, Koç (2000) \%0.302-\%0.712 ve Soyalp (1996) \%0.37-\%1.23 olarak saptamışlardır. Bulunan değerler bu denemedeki sonbahar ekimlerinden elde edilen morfin değerleri ile uyuşmakta, ancak ilkbahar ekimlerinden elde edilen morfin oranlarının yüksek olduğu görülmektedir. Engin (1995) yapmış olduğu çalışmasında, birinci yılda morfin oranının $\% 0.39$, elverişsiz geçen ikinci yılda kapsüldeki morfin oranlarının \%0.46 ile daha yüksek olduğunu bildirmiştir. Emiroğlu (1978) yapmış olduğu bir çalışmasında, elverişsiz geçen ikinci yılda gerek afyondaki morfin oranı ve gerekse kapsüllerdeki morfin oranlarının daha yüksek olduğunu belirtmiştir. Araştırıcı birinci yılda morfin oranının \%0.28, ikinci yılda ise \%0.35 olduğunu bildirmiştir. Kara (2017) farklı haşhaş çeşitleri ile sonbahar ve ilkbaharda yapmış olduğu çalışmasında morfin oranını sonbahar ekimlerinde ortalama \%0.70, ilkbahar ekimlerinde ise ortalama \%0.77 olarak bulmuşlardır. Denememizde sonbahar ve ilkbahar ekimlerinde morfin oranlarındaki farklılıkların sonbahar ekiminde kapsüllerin daha büyük, kapsül duvarlarının daha kalın ve kapsül renginin açık olmasının, ilkbahar ekimlerinde ise kapsüllerin küçük, kapsül duvarlarının ince ve kısım kısım yanıklar olmakla beraber kapsül renklerinin koyu olmasından kaynaklandığı düşünülmektedir. Kapsül boyunun küçülmesine ters orantılı olarak kapsüldeki morfin oranının arttığı görülmektedir.

Haşhaşın büyümesi ve gelişmesi sırasında alkaloidlerin birikimleri ile bunların bileşim değişiklikleri arasında yakın bir ilişki vardır (Vágujfalvi ve Tétényi, 1967). Bunun yanı sıra kullanılan çeşit, biotik ve abiotik stres faktörleri ve ekolojik koşulların alkaloit birikimini etkilediği de bilinmektedir.

Kapsülde alkaloit birikimi ile ilgili araştırmalar hem teorik hem de pratik öneme sahiptir (Bernath ve Nemeth 1998). Bunting ve ark. (1963) ve Schröder (1965), kapsüldeki maksimum morfin birikimine çiçeklenmeden 42 gün sonra ulaşıldığını belirtmişler. Hofman ve Menary (1984) kapsüllerdeki alkaloit yüzdesinin çiçeklenmeden 42 gün sonra maksimuma ulaştığını, çiçeklenmeden 14 gün sonra kapsüldeki kuru madde kaybının bir sonucu olarak morfin yüzdesinin arttığını, belirtmişlerdir. Bununla birlikte, çiçeklenmeden 42-70 gün sonra oluşan kapsüllerde morfin yüzdesinde önemli bir düşüş olduğu tespit edilmiştir. Tohum çimlenmesinden 32, 61, 98, 114 ve 126 gün sonra hasat edilen haşhaşlarda, kapsüllerdeki morfin oranı en yüksek 98. günde hasat edilen kapsüllerden elde edilirken, morfin verimi kapsüllerin daha fazla büyümeleri ve kuru ağırlıklarının fazla olmasından dolayı 126. günde hasat edilen kapsüllerde tespit edilmiştir (Mika, 1955). Araştırıcıların bulguları doğrultusunda çiçeklenmeden sonra periyodun kısalmasının kapsüllerin boyutunun küçülmesine ve ters orantılı olarak alkaloit oranının daha yüksek olmasına sebep olmuştur.

Alkaloit miktarının en fazla kapsül duvarından ekstrakte edildiği, plasentada daha düşük bir miktar ve tohumda da hiçbir etkisi olmayacak kadar bulunduğu belirtilmektedir (Bernath ve Nemeth 1998). Bazı araştırıcılar kapsül sayısı, kapsül boyutu ve kabuk ağırlığı arasında pozitif bir ilişki olduğunu, kapsül boyu ve kabuk ağırlığının afyon verimi ile pozitif olarak ilişkili olduğunu (Kaicker ve ark., 1975; Levy ve Milo, 1998), yine bu bilgilere paralel olarak kapsül sayısı ile kapsül ve tohum verimi arasında pozitif bir korelasyon olduğu, çiçeklenme zamanı ile de kapsül ağırlığı arasında pozitif yönde bir ilişki olduğu (Dubedout, 1993; Shukla ve Khanna, 1987; Levy ve Milo, 1998) belirtilmiştir.

Yapılan bir çalışmada, uzun gün koşullarının haşhaşta gelişimi hızlandırdığı ve çiçek açma zamanının daha erken olduğu, bununla birlikte, kısa gün koşulları altında, bitki kökenine bağlı olarak çiçeklenmede 5-15 gün gecikmeler yaşandığı belirtilmektedir. Kapsüllerde biriken toplam alkaloit miktarının daha yüksek sıcaklık ve aydınlanma ile karakterize edilen tropikal koşullar altında genellikle daha yüksek olduğu vurgulanmaktadır (Bernáth ve ark., 1988).

Sıcaklığın kuru madde üretimi üzerindeki etkisi hem termo regülasyon hem de büyümeyi teşvik eden süreçlerle bağlantılıdır ve onu diğer ekolojik faktörlerin etkileşiminden ayırmak zordur. Bununla birlikte, düşük sıcaklıklarda oluşan kapsüller, yüksek sıcaklığa göre daha büyük ve daha ağırdır (yaklaşık \%10-53) Bitkideki gelişim süreçlerini düzenleyen çevresel koşullar da alkaloit oluşumunu uyarır veya inhibe eder. Bu nedenle, ışık yoğunluğundaki bir artış ve daha yüksek hava sıcaklıkları, genellikle öncü akış ve metilasyon süreçlerinin yoğunlaşması nedeniyle alkaloidlerin birikmesini hızlandırır (Bernath ve Nemeth, 1998).

İklim değişikliğinin 2100 yılına kadar haşhaş üretim alanlarına etkisi ile ilgili yapılan çalışmada, ortalama sıcaklık değerlerindeki artış ile birlikte haşhaş ekim alanlarında zamanla azalışa sebep olacağı bununla 
birlikte ekstrem hava olaylarının oluş sıklığının artması ile haşhaş ve diğer ürünlerinde bundan olumsuz etkileneceğini belirtmişlerdir (Yıldırım ve ark., 2016). Haşhaş vejetasyon süresi boyunca aylık ortalama sıcaklık değerlerinin, uzun yıllar ortalama değerlerine göre genellikle yüksek seyretmesi ve özellikle ilkbahar ekimlerinde karşılaşılan sorunlar araştırmacıların belirtmiş olduğu ekim alanlarındaki daralmaya da işaret etmektedir.

Sonuç olarak, Türkiye'de olduğu gibi Uşak ilinde de güzlük ekimi yapılan haşhaş alanlarında bazı yıllarda sert geçen kış ayları nedeniyle haşhaş ekim alanlarının zarar gördüğü, hatta bazı yörelerde güzlük ekimlerin sürülerek bozulduğu bilinmektedir. Kimi yörelerde bozulan bu haşhaş alanlarında bahar aylarında yeniden haşhaş ekiminin yapılması söz konusu olabilmektedir. Ancak bahar dönemi yapılan ekimlerde de güzlük ekimlere nazaran verim düşüklükleri olmaktadır. Bu durum bilinen bir husustur. Ancak yapılan bu araştırma; Uşak ilinde güzlük ekim yanında bahar döneminde yapılacak olan haşhaş ekimlerinde yöre için en uygun ekim zamanın ne zaman olacağının net olarak ortaya konulmasını sağlamıştır. Kışları sert geçen yıllarda haşhaş ekimlerinin yenilenmesi gerektiğinde yöreye en uygun ekim zamanın belirlenmesi bu yüzden önem arz etmektedir.

Kapsül/dane verimi ve morfin verimi olarak sonbahar ekilişe alternatif en uygun ilkbahar ekim zamanı şubatın ilk 15 günü olsa da, ilkbahar ekimler ekonomik olmamakta ve kesinlikle sonbahar ekiminin yerini tutmamaktadır.

Daha önceleri diğer araştırıcılar tarafından yapılmış çalışmalarda olduğu gibi bu araştırmada elde ettiğimiz bulgular neticesinde; ekolojik faktörlerin ve stres koşullarının haşhaşta verim ve verim kriterleri ile kapsüldeki kuru madde birikimi ve alkaloit üretimi ile ilişkili olduğu belirtilebilir. Bu faktörlerden sıcaklık, vejetasyon süresi ve suyun önemli bir etkisi olduğu görülmektedir. Özellikle küresel ısınmadan dolayı ortalama sıcaklık değerlerinin artması ve yağıştaki düzensizlikler in vivo şartlarda kontrolü mümkün olmayan agronomik karakterlere ve verime doğrudan etki etmektedirler. illkbahar ekimlerinde vejetasyon süresinin kısa olması, bahar aylarında sıcaklıkların artması nedeni ile mart ayı içerisindeki ekimlerde de bitkiler büyük oranda zarar görmektedir. Şubat ayı içerisindeki ekimlerde verim olumsuz yönde etkilenmektedir. Bahar dönemi erken yapılan ekimlerde havaların ısınmasına paralel olarak bitkinin verim kriterlerinde düşüş görülmekte iyi rozet oluşturamayan bitkilerin havaların ısınmasıyla hızlı şekilde generatif devreye geçmesine dolayısıyla bitkilerin çok gelişemeden kısa boylu ve cılız bir şekilde sapa kalmasına neden olmaktadır. Bitki boyu ve kapsül iriliklerinde ciddi düşüş olduğu bu dönemde kapsüllerde oluşan alkaloit miktarında ise artışlar görülmüştür. Her ne kadar alkaloit içerikleri artış gösterse de elde edilen kapsül verimin düşük olması birim alandan elde edilen alkaloit verimini de düşürmektedir.

Küresel ısınmanın etkisini sıcaklık artışı şeklinde bundan sonra daha fazla hissedeceğimiz düşünüldüğünde, önümüzdeki yıllarda ilkbaharda haşhaş ekiminin ekonomik olmaktan çıkacağı bu çalışmada çarpıcı bir şekilde görülmektedir. Tarım sektörü olarak, küresel ısınma ve iklim değişikliğine yönelik alınabilecek tedbirler noktasında daha fazla çalışma yapılması, mukavemeti yüksek yeni çeşitlerin geliştirilmesi gerektiği değerlendirilmektedir.

\section{ÖZET}

Amaç: Bu çalışma, Uşak ili ekolojik şartlarında sonbahar ve ilkbahar alternatif ekim zamanlarının haşhaşın (Papaver somniferum L.) verim ve verim kriterlerine etkisinin belirlenmesi amacıyla 2017/2018 ve 2018/2019 üretim yıllarında Uşak îli Koyunbeyli köyünde, çiftçi tarlasında iki yıllık olarak yürütülmüştür.

Yöntem ve Bulgular: Çalışmada, "Ofis 3" haşhaş çeşidi materyal olarak kullanılmıştır. Deneme, tesadüf blokları deneme desenine göre, üç tekerrürlü olarak kurulmuştur. Çalışmada, bitki boyu, bitki başına kapsül sayısı, kapsül boyu, kapsül eni, kapsül verimi, tohum verimi ve morfin oranı incelenmiştir. Morfin oranı (\%) dışında incelenen diğer tüm özelliklerde her iki yılda da sonbahar ekiminde en yüksek değerler elde edilmiştir. Sonbahar ekimine alternatif olarak düşünülen şubat başında ve ortasında yapılan ilkbahar ekimlerinde morfin oranları yüksek çıkmış ancak ölçümü yapılan diğer karakterlerin(bitki boyu, bitki başına kapsül sayısı, kapsül boyu ve eni, kapsül verimi, tohum verimi) yüksek oranda olumsuz etkilendikleri tespit edilmiştir. Mart başı ve ortasında yapılan ekimlerde ise verim alınamamıştır. Haşhaş kapsüllerindeki morfin oranı sonbahar ekiminde \%1.07-1.17, ilkbahar ekiminde \%1.29-1.46 arasında değişim göstermiştir. Her iki yıl da elde edilen kapsül verimi ve tohum verimi sonbahar ekiminde sırası ile 105.28-107.11 ve $112.61-116.78 \mathrm{~kg} \mathrm{da}^{-1}$, ilkbaharda ekiminde sırası ile $17.55-21.67$ ve $15.10-15.77 \mathrm{~kg} \mathrm{da}^{-1}$ bulunmuştur.

Genel Yorum: Çalışmada, sonbahar ekimine alternatif olabilecek ekim döneminin 1 Şubat ile 15 Şubat tarihleri arasında olabileceği, ancak belirtilen tarihlerdeki verim ve verim kriterlerinin sonbahar ekimine göre belirgin bir şekilde daha düşük olduğu tespit edilmiştir.

Çalışmanın Önemi ve Etkisi: Meteorolojik 
parametrelerin ortalama iklim değerlerinden sapma göstermesi her iki yılda da özellikle de ilkbahar ekiminde haşhaş gelişimini ciddi oranda olumsuz etkilemiştir. İlerleyen yıllarda küresel ısınmanın etkilerini daha fazla göreceğimiz düşünüldüğünde haşhaşın yalnızca sonbaharda ekimi tavsiye edilebilir.

Anahtar Kelimeler: Alternatif ekim zamanı, küresel ısınma, sekonder metabolit, alkaloid.

\section{TEŞEKKÜR}

Bu çalışma, Uşak Üniversitesi, Lisansüstü Eğitim Enstitüsü, Tarım Bilimleri Anabilim Dalı yüksek lisans öğrencisi tez çalışmasından hazırlanmıştır.

\section{ÇIKAR ÇATIŞMA BEYANI}

Yazarlar çalışma konusunda çıkar çatışmasının olmadığını beyan eder.

\section{ARAŞTIRMACILARIN KATKI ORANI BEYANI}

Yazarlar çalışmaya eşit oranda katkı sağlamış olduklarını beyan eder.

\section{KAYNAKLAR}

Alaca F (2015) Farklı haşhaş tiplerinde alkaloidler yönünden morfolojik ve ontogenetik varyabilite. Doktora Tezi, Ankara Üniversitesi, Fen Bil. Ens., Tarla Bitkileri ABD, $143 \mathrm{~s}$.

Anonim (2020) Toprak Mahsulleri Ofisi Genel Müdürlüğü, Haşhaş Raporu 2019. Ankara, 2020.

Anonim (2021) Tubives, Türkiye Bitkileri veri servisi http://www.tubives.com/ (Erişim Tarihi:15 Nisan 2021).

Bernáth J, Dános B, Veres T, Szantó J, Tétényi P (1988) Variation in alkaloid production in poppy ecotypes: Responses to different environments. Biochem. Syst. Ecol. 16(2): 171-178.

Bernath J, Nemeth E (1998) Physiological-Ecological Aspects, In: Poppy: the genus Papaver (Eds Bernath J), Harwood Academic Publishers, The Netherlands. pp 74-100.

Boydak E, Kavurmacı Z (2015) Doğu geçit bölgesinde bazı haşhaş (Papaver somniferum L.) çeşitlerinin adaptasyonu. Tr. Doğa ve Fen Derg. - Tr. J. Nature Sci. 4(1): 44-47.

Bunting ES, Coic $Y$, Lesaint C, Papain JL, Lelandais M (1963) Changes in the capsule of Papaver somniferum between flovering and maturity. Ann. Appl. Biol. 51: 459-471.
Büyükgöçmen R (1993) Farklı yörelerden temin edilen yerli yabancı haşhaş (Papaver somniferum L.) popilasyonlarının bazı bitkisel özellikleri. Yüksek Lisans Tezi, Ankara Üniversitesi, Fen Bil. Ens., Tarla Bitkileri ABD, $78 \mathrm{~s}$.

Davis PH, Mill RR, Tan K (1988) Papaver L. Flora of Turkey and East Aegean Islands. Univ. Pres.,Edinburg.

Dubedout M (1993) Analysis of progenies from a circular plan of crosses in poppy (Papaver somniferum L.). PhD Thesis, Universiy of Paris, Orsay, 101 p.

Emiroğlu ŞH (1978) Çizilen ve çizilmeyen haşhaşlarda (Papaver somniferum L.) bitki ve tohum özellikleri ile afyonda ve kapsülde morfin alkoloidi üzerinde araştırmalar. Ege Üniversitesi Ziraat Fakültesi, Yayın No:370, Bornova, izMiR.

Engin D (1995) Azot dozları ve hasat zamanının haşhaş (Papaver somniferum L.)'da verim ve kalite üzerine etkisi Doktora Tezi, Uludağ Üniversitesi, Fen Bil. Ens., Tarla Bitkileri ABD, $95 \mathrm{~s}$.

Er C, Yıldız M (2007) Keyf Bitkileri. Ankara Üniversitesi, Ziraat Fakültesi, Tarla Bitkileri Bölümü, Yayın No:1555. Ankara. 251s.

Erdurmuş A (1989) Haşhaş (Papaver somniferum L.) hatlarında fenolojik ve morfolojik karakterlerin morfin ve tohum verimiyle ilişkileri. Doktora Tezi, Ankara Üniversitesi, Fen Bil. Ens., Tarla Bitkileri ABD, $58 \mathrm{~s}$.

Eser B, Saygılı H, Gökçöl A, Illker E (2006) Tohum bilimi ve teknolojisi. Ege Üniversitesi Tohum Teknolojisi Uygulama ve Araştırma Merkezi Yayınları. Cilt:1. İzmir.

Gümüşcü A (1996) Seçilmiş bazı haşhaş (Papaver somniferum L.) çeşit ve hatlarının verim öğelerinin karşıllaştırılması. Yüksek Lisans Tezi, Ankara Üniversitesi, Fen Bil. Ens., Tarla Bitkileri ABD, $81 \mathrm{~s}$.

Gümüşçü A (2002) Seçilmiş $P$. somniferum hatlarının melezlerinde verim ve bazı özelliklerinde heterosis üzerine araştırmalar. Doktora Tezi, Ankara Üniversitesi, Tarla Bitkileri ABD, $109 \mathrm{~s}$.

Gümüş̧̧ü A, Arslan N (1999) Seçilmiş bazı haşhaş (Papaver somniferum L.) çeşit ve hatlarının verim öğelerinin karşılaştırılması. Turk J Agric For. 23(Ek Sayı 4): 991-997.

Hofman PJ, Menary RC (1984) Losses, by leaching, of alkaloids from the capsule of poppy (Papaver somniferum L.) during maturation. Aust. J. Agric. Res. 35(2): 253-261.

İnan Ş (2013) Haşhaşta (Papaver somniferum L.) bazı tarımsal özellikler ile yağ ve morfin miktarının belirlenmesi. Doktora Tezi, Ankara Üniversitesi, Fen Bil. Ens., Tarla Bitkileri ABD, 49 s. 
İncekara F (1949) Türkiye haşhaş çeşitleri ve bunların tohum ve afyon bakımından değerleri. Toprak Mahsülleri Ofisi Yayını, Çankaya Matbaası, Ankara. $376 \mathrm{~s}$.

Kaicker US, Singh US, Bakrishnan KA, Singh HP, Choudhury B (1975) Correlation and path coefficient analysis of opium poppy. Genet. Agr. 29: 357-370.

Kara N (2017) The effects of autumn and spring sowing on yield, oil and morphine contents in the Turkish poppy (Papaver somniferum L.) cultivars. Turk. J. Field Crops 22(1): 39-46.

Karadavut U (1994) Yabancı kökenli haşhaş (Papaver somniferum L.) çeşit ve populasyonlarının bazı bitkisel özellikleri. Yüksek Lisans Tezi, Ankara Üniversitesi, Fen Bil. Ens., Tarla Bitkileri ABD, $99 \mathrm{s.}$

Koç H (2000) Bazı haşhaş çeşitlerinde farklı gölgeleme ve sıra üzeri uygulamalarının verim ve verim unsurları üzerine etkileri. Doktora Tezi, Selçuk Üniversitesi, Fen Bil. Ens., Tarla Bitkileri ABD, $71 \mathrm{~s}$.

Levy A, Milo J (1998) Genetics and breeding of Papaver somniferum, In: Poppy: the genus Papaver (Eds Bernath J), Harwood Academic Publishers, The Netherlands. pp 101-111.

Malinia VM, Ivanova RM (1975) Cultivars of oilseed poppy with high contents of alkaloids. Field Crop Abstr. No: 7461. Moscow, Russian.

Mika ES (1955) Studies of the growth and development and morphine concentration of opium poppy. Int. J. Plant Sci. 116(4): 323-339.
Rezaeı Osalou A (2015) Tescilli Haşhaş (Papaver somniferum L.) Çeşitlerinin Tarımsal Değerlerinin Karşılaştırılması. Doktora Tezi, Ankara Üniversitesi, Fen Bil. Ens., Tarla Bitkileri ABD, $147 \mathrm{~s}$.

Sarıhan EO (2004) Haşhaş (Papaver somniferum L.) Bitkisinin Verimi ve Bazı Özellikleri Üzerine Giberellik Asidin (GA3) Farklı Doz ve Uygulama Zamanlarının Etkisi. Doktora Tezi, Ankara Üniversitesi, Fen Bil. Ens., Tarla Bitkileri ABD, $118 \mathrm{~s}$.

Schröder H (1965) Studies on the changes in the morphine content of ripening poppy capsules. Pharmazie 20: 169-171.

Shukla S, Khanna KR (1987) Genetic association in opium poppy. Ind. J. Agric. Sci. 57(3): 147-151.

Soyalp C (1996) Morfin oranı yüksek haşhaş (Papaver somniferum L.) hatlarının kapsül ve tohum verimleri üzerine bir araştırma. Yüksek Lisans Tezi, Ankara Üniversitesi, Fen Bil. Ens., Tarla Bitkileri ABD, 79 s.

Vágujfalvi D, Tétényi P (1967) Mákalkaloidok bioszintézise. Herba Hungarica 6(2):221-230.

Yıldırım MU, Demircan M, Özdemir FA, Sarıhan EO (2016) İklim değişikliğinin haşhaş (Papaver somniferum L.) üretim alanlarına etkisi. Tarla Bitkileri Merkez Araştırma Enstitüsü Dergisi 25(Özel sayı-2):289-295. 